\title{
Interaction Between Zinc, Cadmium, and Lead in Scalp Hair Samples of Pakistani and Irish Smokers Rheumatoid Arthritis Subjects in Relation to Controls
}

\author{
Hassan Imran Afridi \& Tasneem Gul Kazi \& Dermot Brabazon \& Sumsun Naher
}

\begin{abstract}
The incidence of rheumatoid arthritis (RA) has been associated with cigarette smoking. The aim of our study was to assess the trace essential and toxic metals, cadmium $(\mathrm{Cd})$, lead $(\mathrm{Pb})$, and zinc ( $\mathrm{Zn})$, in scalp hair samples of 32 Irish and 46 Pakistani smokers and non-smokers RA male patients with age range 42-56 years. For comparison purpose, the scalp hair samples of 27 Irish and 55 Pakistani non-RA male subjects of the same age group were collected. The concentrations of trace and toxic elements were measured by inductive coupled plasma atomic emission spectrophotometer and atomic absorption spectrophotometer prior to microwave-assisted acid digestion. The validity and accuracy of the methodology was checked using certified reference materials and using conventional wet acid digestion method on the same certified reference materials (CRMs). The recovery of all studied elements was found to be in the range of 97.5-99.7\% of certified reference values of CRMs. The results of this study showed that the mean values of $\mathrm{Cd}$ and $\mathrm{Pb}$ were significantly higher in scalp hair samples of both smoker and non-smoker RA patients than in referents $(\mathrm{P}<0.001)$, whereas the concentration of $\mathrm{Zn}$ was lower in the scalp hair samples of smokers and non-smokers rheumatoid arthritis patients. The deficiency of $\mathrm{Zn}$ and the high exposure of $\mathrm{Cd}$ and $\mathrm{Pb}$ as a result of cigarette smoking may be synergistic risk factors associated with rheumatoid arthritis.
\end{abstract}

Keywords: Scalp hair $\bullet$ Zinc $・$ Toxic elements $\bullet$ Pakistani rheumatoid arthritis patients $\bullet$ fish rheumatoid arthritis patients $\bullet$ Atomic absorption spectrophotometer $\bullet$ Inductively coupled plasma atomic emission spectrophotometer.

\section{Introduction}

Rheumatoid arthritis (RA), a systemic skeletal disease characterized by a low bone mass, is a major public health problem in elderly persons resulting in high incidence of fragility fractures, especially hip and vertebral fracture. In these people, the high incidence of osteoporotic fractures leads to considerable mortality, morbidity, reduced mobility, and decreased quality of life [1].

A variety of trace elements are found in bones including iron, copper $(\mathrm{Cu})$, zinc $(\mathrm{Zn})$, manganese (Mn), fluoride, strontium, and boron [2]. Although they are present in only minute amounts, trace elements influence normal metabolic processes through interaction 
with, or incorporation into, proteins, particularly enzymes [3]. The role of $\mathrm{Zn}$ in healthy aging is particularly important as it prevents neoplastic cell growth and is involved in mitotic cell division, and DNA and RNA repair. Chronic diseases associated with alterations in Zn status are bronchial asthma and rheumatoid arthritis [4]. Zinc plays an important role in nucleic acid synthesis, transcription, and translation as a cofactor for some of the enzymes involved and may therefore participate in a broad range of metabolic activities in bone. Alkaline phosphate is required for bone calcification, and collagenase is required for bone resorption and remodeling [5]. It has been demonstrated that $\mathrm{Zn}$ deficiency reduces the synthesis and activity of alkaline phosphate in rats [6], and the activity of collagenase in chicks [7]. Zinc deficiency has also been reported to interfere with glycosami-noglycan metabolism of membranous bone and osteoblastic activity in experimental animals [8]. In addition, $\mathrm{Zn}$ has been shown to stimulate bone formation and to inhibit osteoclastic activity in vitro [9].

Cigarette design has evolved considerably over the last few decades with the incorporation of new tobacco process-es, papers, filters, and several ingredients (flavor, humectants, and casing materials), which either alone or in combination have the potential to modify the quantity and/ or the quality of the smoke yielded [10]. The tobacco plant absorbs heavy metals most probably from the soil, fertilizers, or pesticides [11]. Other environmental factors that may influence the uptake of toxic elements by tobacco plants include the $\mathrm{pH}$ of soil, and contaminated irrigated water and sewage sludge used as fertilizers. Tobacco smok-ing delivers 87 organic carcinogens to the lungs, in addition to toxic elements [12], which may partition into the smoke phase on combustion [12]. Some of these [cadmium (Cd), nickel $(\mathrm{Ni})$, and lead $(\mathrm{Pb})]$ readily pass into the bloodstream and may accumulate in specific organs, such as the kidney and liver [13]. There are a few studies that have reported on the large variations of toxic elements in the compositions of commercial tobacco products, which have tried to link smoking-related diseases with toxic elements derived from tobacco combustion [14]. The intake of trace and toxic elements may promote rheumatoid arthritis disorders by increasing oxidative stress (for example, by catalyzing the production of reactive oxygen species or inhibiting their degradation) due to the deficiency of antioxidant elements ( $\mathrm{Zn}, \mathrm{Cu}$, and $\mathrm{Mn}$ ). The deficiency of essential nutrients, lack of homeostatic control, or an excess intake of some toxic elements causes chronic physiological disorders, such as hypertension, cardiovascular disease, and rheumatoid arthritis [15] .

Determinations of trace elements in human tissues and fluids were used to obtain information on nutritional status for diagnosis of diseases, indication of systemic intoxication, and to obtain information on environmental exposure. In the majority of cases, whole blood, serum, plasma, and urine were analyzed [16]. Hair can provide a more permanent record of trace and toxic elements associated with normal and abnormal metabolism as well as toxic elements assimilated from the environment. In addition, hair is easily collected, conveniently stored, and easily treated. Therefore, the analysis of human hair has become an important way to understand any quantitative change in certain elements in-side the body [17].

One of the most widely used analytical techniques for the determination of different elements in biological and environ-mental materials are atomic absorption spectrometry and inductively coupled plasma atomic emission spectrometry due to its advantages over other 
analytical techniques [18]. The mineralization method is most frequently applied for the analysis of biological samples or wet digestion with concentrated acids using either conventional heating or microwave energy for oxidizing the organic matter [16].

The main advantage of microwave-assisted samples pretreatment is its requirement of small amount of mineral acids and a reduction in the production of nitrous vapors. Microwave systems keep blank levels low because only small volumes of reagents are required and allow more samples to be processed per hour than conventional digestion systems [19].

The aim and objective of our present study was to assess the concentrations of $\mathrm{Cd}, \mathrm{Pb}$, and $\mathrm{Zn}$ in the scalp hair samples of Pakistani and Irish male smoker rheumatoid arthritis patients. For a comparative study, 27 Irish and 55 Pakistani non-rheumatoid arthritis individuals (smoker and non-smokers) of the same age group (range 42-56 years), socioeconomic status, localities, and dietary habits were selected as referents. The metal levels were also examined for a possible mutual correlation and were compared with reported metal levels for donors from other regions of the world. It was anticipated that the comparative metal levels in hair of Pakistani and Irish referent segments would bring out distinct sources responsible for the distribution of selected metals to help assess the nutritional status and environmental exposure of the two categories of subjects compared with those from other nations where different environmental and living conditions prevail.

\section{Materials and Methods}

\section{Apparatus}

The analysis of elements in Ireland was carried out by means of a Varian Liberty 220 (Mulgrave, Victoria, Australia) Inductively Coupled Plasma Atomic Emission Spectrometer using the axially viewed plasma. The Liberty Series II ICP features a 40-MHz free running $\mathrm{RF}$ generator and a $0.75-\mathrm{m}$ Czerny-Turner monochromator with 1,800 grooves $/ \mathrm{mm}$ holographic grating used in up to four orders. The resolution of the spectrometer is typically $0.018 \mathrm{~nm}$ in first order, $0.009 \mathrm{~nm}$ in second order, $0.007 \mathrm{~nm}$ in third order, and $0.006 \mathrm{~nm}$ in fourth order. The instrument was controlled with a Digital Equipment Corporation (DEC) Venturis computer with an Intel Pentium processor and Varian Plasma 96 software running under Microsoft Windows 95 operating system. The instru-mental conditions are shown in Tables 1 and 2. A Hinari Life style (Elstree, Hertfordshire, UK) domestic microwave oven (maximum heating power of $800 \mathrm{~W}$ ) was used for digestion of the scalp hair samples.

The analysis of elements in Pakistan was carried out by means of a double beam PerkinElmer atomic absorption spectrometer model 700 (Norwalk, CT, USA) equipped with a flame burner and graphite furnace HGA-400, a pyrocoated graphite tube with an integrated platform, and an autosampler AS-800 (Perkin Elmer). 
Table 1 Measurement conditions for inductive coupled plasma atomic emission spectroscopy Liberty 220 ICP-AES

\begin{tabular}{|c|c|c|c|}
\hline Parameters & $\mathrm{Cd}$ & & $\mathrm{Zn}$ \\
\hline Wavelength (nm) & 226.502 & 220.553 & 213.8 \\
\hline Height (mm) & 3 & 3 & 5 \\
\hline $\begin{array}{l}\text { Windows }(\mathrm{nm}) \text { (above } \\
\text { the coil) }\end{array}$ & 0.027 & 0.027 & 0.027 \\
\hline Scan $(\mathrm{nm})$ & 0.040 & 0.040 & 0.040 \\
\hline Integration (s) & 3 & 3 & 3 \\
\hline Replicates & 3 & 3 & 3 \\
\hline Sample uptake (s) & 30 & 30 & 30 \\
\hline PMT (V) & 650 & 650 & 650 \\
\hline Power (kW) & 1.10 & 1.10 & 1.10 \\
\hline Plasma flow (1/min) & 15.0 & 15.0 & 15.0 \\
\hline Auxiliary flow (1/min) & 1.50 & 1.50 & 1.50 \\
\hline Pump speed (rpm) & 15 & 15 & 15 \\
\hline Background mode & Dynamic & mic & Dynamic \\
\hline Max curve order & 1 & 1 & 1 \\
\hline C.C. limit & 0.995 & 0.995 & 0.995 \\
\hline \multirow[t]{9}{*}{$\begin{array}{ll}\text { Table } 2 & \text { Liberty } 220 \\
\text { common parameters }\end{array}$} & Nebulizer type & \multicolumn{2}{|c|}{ V-groove } \\
\hline & $\begin{array}{r}\text { Nebulizer } \\
\text { pressure }\end{array}$ & \multicolumn{2}{|c|}{$150 \mathrm{kPa}$} \\
\hline & Stabilization time & \multicolumn{2}{|l|}{$10 \mathrm{~s}$} \\
\hline & $\begin{array}{l}\text { Sample delay } \\
\text { time }\end{array}$ & \multicolumn{2}{|l|}{$30 \mathrm{~s}$} \\
\hline & Rinse time & \multicolumn{2}{|l|}{$10 \mathrm{~s}$} \\
\hline & Pump-tube & \multicolumn{2}{|c|}{$\begin{array}{l}\text { Orange-orange } \\
\text { (inlet) }\end{array}$} \\
\hline & & \multicolumn{2}{|c|}{ Blue-blue (outlet) } \\
\hline & Snout purge & \multicolumn{2}{|l|}{ Off } \\
\hline & Fast pump & \multicolumn{2}{|l|}{ On } \\
\hline
\end{tabular}

The instrumental parameters are shown in Table 3. Zn was measured under optimized operating conditions using FAAS with an air-acetylene flame, whereas $\mathrm{Cd}$ and $\mathrm{Pb}$ were determined using ETAAS. Signals were measured as absorbance peaks in the flame absorption mode, whereas integrated absorbance values (peak area) were determined in the graphite furnace. A Pel (PMO23, Osaka, Japan) domestic microwave oven (maxi-mum heating power of $900 \mathrm{~W}$ ) was used for digestion of the scalp hair samples. Acid-washed PTFE (polytetrafluoro-ethylene) vessels (Kartell, Milan, Italy) and flasks were used for preparing and storing solutions. 
Table 3 Measurement conditions for elements using flame and electrothermal atomic absorption spectrometry

Sample volume $=10 \mu \mathrm{l}$, cuvette $=$ cup, carrier gas $=$ $200 \mathrm{ml} / \mathrm{min}$. Background correction $\left(\mathrm{D}_{2}\right.$ lamp) used for all elements

\begin{tabular}{llll}
\hline Parameters & $\mathrm{Cd}$ & $\mathrm{Pb}$ & $\mathrm{Zn}$ \\
\hline Lamp current (MA) & 6.0 & 8.0 & 7.5 \\
Wavelength (nm) & 228.8 & 283.3 & 213.8 \\
Slit width (nm) & 0.7 & 0.7 & 0.7 \\
Dry temperature $\left({ }^{\circ} \mathrm{C}\right) / \mathrm{ramp} /$ hold $(\mathrm{s})$ & $140 / 15 / 5$ & $140 / 15 / 5$ & Burner height $=7.5 \mathrm{~mm}$ \\
Ashing temperature $\left({ }^{\circ} \mathrm{C}\right) / \mathrm{ramp} / \mathrm{hold}(\mathrm{s})$ & $850 / 10 / 20$ & $700 / 10 / 20$ & Oxidant $($ air $)=17.0 \mathrm{lmin}^{-1}$ \\
Atomization temperature $\left({ }^{\circ} \mathrm{C}\right) / \mathrm{ramp} / \mathrm{hold}$ & $1,650 / 0 / 5.0$ & $1,800 / 0 /$ & Fuel (acetylene $)=2.01$ \\
$\quad(\mathrm{~s})$ & & 5.0 & min $^{-1}$ \\
Cleaning temperature $\left({ }^{\circ} \mathrm{C}\right) / \mathrm{ramp} / \mathrm{hold}(\mathrm{s})$ & $2,600 / 1 / 3$ & $2,600 / 1 / 3$ & \\
Chemical modifier & $\mathrm{Mg}\left(\mathrm{NO}_{3}\right)_{2}+\mathrm{Pd}$ & $\mathrm{Mg}\left(\mathrm{NO}_{3}\right)_{2}$ & \\
& $\left(\mathrm{NO}_{3}\right)_{2}$ & & \\
\hline
\end{tabular}

\section{Reagents and Glasswares}

Ultrapure water obtained from ELGA Lab Water system (Bucks, UK) was used throughout the work. Concentrated nitric acid (65\%) and hydrogen peroxide $(30 \%)$ were obtained from Merck (Darmstadt, Germany) and checked for possible trace metal contamination. Working standard solutions of $\mathrm{Cd}, \mathrm{Pb}$, and $\mathrm{Zn}$ were prepared immediately prior to their use, by stepwise dilution of certified standard solutions (1,000 ppm) Fluka Kamica (Buchs, Switzerland), with $0.5 \mathrm{M} \mathrm{HNO}_{3}$. All solutions were stored in polyethylene bottles at $4^{\circ} \mathrm{C}$.

For the accuracy of methodology, the certified reference materials (CRMs), human hair NCSZN 81002b (Beijing, China), and certified reference materials (CRMs) of human hair BCR 397 (Brussels, Belgium) were used (Table 4). All glassware and plastic materials used were previously soaked for $24 \mathrm{~h}$ in $5 \mathrm{M}$ nitric acid, washed with distilled water and finally rinsed with ultrapure water, dried, and stored in class 100 laminar flow hoods.

Table 4 Determination of trace elements in certified sample of human hair (CRM) by conventional (CDM) and microwave digestion method (MWD) $(n=10)$

\begin{tabular}{|c|c|c|c|c|c|}
\hline Elements & Conventional digestion method CDM & Microwave digestion method MWD & $T$ value $^{\mathrm{a}}$ & $\%$ recovery $^{\mathrm{b}}$ & Certified values \\
\hline \multicolumn{6}{|c|}{ Certified human hair reference material (NCS ZC 81002b) ( $\mu \mathrm{g} / \mathrm{g})$} \\
\hline $\mathrm{Cd}$ & $0.0716 \pm 0.003(4.19)$ & $0.0714 \pm 0.006(8.40)$ & 0.305 & 99.7 & $0.072 \pm 0.010$ \\
\hline $\mathrm{Pb}$ & $3.80 \pm 0.37(9.74)$ & $3.72 \pm 0.35(9.41)$ & 0.081 & 98.05 & $3.83 \pm 0.18$ \\
\hline $\mathrm{Zn}$ & $191 \pm 7.28(3.81)$ & $187 \pm 9.53(5.09)$ & 0.648 & 97.9 & $191 \pm 16$ \\
\hline \multicolumn{6}{|c|}{ Certified human hair material CRM 397 ( $\mu \mathrm{g} / \mathrm{g})$} \\
\hline $\mathrm{Cd}$ & $0.53 \pm 0.025(4.72)$ & $0.524 \pm 0.024(4.58)$ & 0.2256 & 98.87 & $0.52 \pm 0.024$ \\
\hline $\mathrm{Pb}$ & $33.29 \pm 1.21(3.63)$ & $32.56 \pm 1.18(3.62)$ & 0.096 & 97.8 & $33 \pm 1.2$ \\
\hline $\mathrm{Zn}$ & $197 \pm 12.8(6.2)$ & $194 \pm 11.3(5.7)$ & 0.0345 & 98.6 & $199 \pm 5$ \\
\hline
\end{tabular}

a Paired $t$ test between CDM and MWD, $d f=9, T$ (critical) at 95\% CI=2.262, $P=0.05$. Means in percentage. Values in parentheses are RSD

$\mathrm{b} \%$ recovery was calculated according to the following: $\frac{[\mathrm{MDM}]}{[\mathrm{CDM}]} \times 100$ 


\section{Sample Collection and Pretreatment}

This study was completed in two phases. Phase 1 was completed during January 2005 to June 2006 and phase 2 during July 2010 to October 2010. The sampling locations were Hyderabad, Pakistan and Dublin, Ireland. The donor ages of both countries ranged between 42 and 56 years from each location. Before the start of this study, all referents and rheumatoid arthritis patients of both countries were in-formed through a consent form by the administration about the aim of study, and all agreed to participate and signed the form. A questionnaire was also administered to them to collect details regarding physical data, ethnic origin, health, duration and frequency of smoking, dietary habits, age, and consent. The RA patients were grouped according to their habits - non-smokers (NSRA) and smokers (SRA). While control groups were also divided into two groups, referent non-smokers (RNS) and smokers (RS) are shown in Table 5.

Table 5 The number of subjects as control and rheumatoid arthritis patients of age group 42-56 years

\begin{tabular}{lccccc}
\hline \multirow{2}{*}{ Countries } & \multicolumn{2}{l}{ Referents } & & \multicolumn{2}{c}{ Rheumatoid arthritis } \\
\cline { 2 - 3 } \cline { 5 - 6 } \cline { 5 - 6 } & Smokers & Non-smokers & & Smokers & Non-smokers \\
\hline Pakistan & 47 & 52 & & 39 & 34 \\
Ireland & 22 & 19 & & 23 & 20 \\
\hline
\end{tabular}

All the patients had active disease defined by the following criteria: erythrocyte sedimentation rate (ESR) of at least $30 \mathrm{~mm} / \mathrm{h}$, six or more tender joints, three or more swollen joints, and morning stiffness of at least 30-min duration. Thirty Irish and 37 Pakistani patients had IgM-positive rheumatoid factor. None of the patients had been treated with steroids, immunosuppressives, or penicillamine within the 3 months before the study. They all were receiving non-steroidal anti-inflammatory drugs (NSAIDs) (diclofenac so-dium, 100 $\mathrm{mg} /$ day).

Physical examinations were carried out in a basic health unit of Hyderabad, Pakistan and Dublin, Ireland to measure participant's weight, height, blood pressure, and biochemical data.

For all patients and referents, anthropometric parameters including weight, height, and waist circumference were measured using the standard protocols. There were no statistically significant differences between both groups of patients and referents with regard to height and weight. The study protocol was approved by the local ethics committee of higher education commission, Islamabad, Pakistan. The criteria of healthy subjects included no history of symptoms of any related disease to arthritis documented in their medical notes. All control subjects underwent a routine medical examination. The dietary habits of Pakistani 
people (elder age group) depend upon animals (chicken, mutton, beef) and plants (vegetables, beans and grain) while the Irish people used chicken, vegetables, and beans.

\section{Collection of Scalp Hair Samples}

The hair samples $(-1.0 \mathrm{~g}$ each) were taken from the nape of the neck. Hair samples were put into separate plastic envelopes for each participant on which the identification (ID) number of the participant was indicated. The plastic envelope of each subject was tightly sealed and attached to a questionnaire.

Before analysis, each individual hair sample was cut into approximately 0.5 -cm-long pieces and mixed to allow a representative subsampling of the hair specimen. After cutting, each sample was washed with diluted Triton X-100; samples were then rinsed with distilled water and then with deionized water. The samples were rinsed three times with acetone [19]. All samples were then dried in an oven at $75 \pm 5^{\circ} \mathrm{C}$ for $2 \mathrm{~h}$. Dried samples were stored separately in polyethylene bags.

\section{Microwave-Assisted Acid Digestion (MWD)}

Duplicate samples of scalp hair (200 mg) of each RA patients and control individuals were directly placed into Teflon PFA flasks. Two milliliters of a freshly prepared mixture of concentrated HNO3 - H202 (2:1, v/v) was added to each flask and kept for $10 \mathrm{~min}$ at room temperature then placed in a covered PTFE container. This was then heated following a onestage digestion program at $80 \%$ of total power $(800 \mathrm{~W})$. Complete digestion of scalp hair samples required 5-8 min. After the digestion, the flasks were left to cool and the resulting solution was evaporated to semidried mass to remove excess acid. About $5 \mathrm{ml}$ of $0.1 \mathrm{M}$ nitric acid was added to the residue and filtered through a Whatman no. 42 filter paper and diluted with deionized water up to $10.0 \mathrm{ml}$ in volumetric flasks.

Blank extractions were carried through the complete procedure. Blanks and standard solutions were prepared in a similar acid matrix. The validity and efficiency of the MWD method was checked with certified values of human hair NCSZC 81002b and certified human hair CRM 397 and with those obtained from conventional wet acid digestion method [17].

\section{Analytical Figures of Merit}

Statistical analyses were performed using computer program Excel XL State (Microsoft Corp., Redmond, WA, USA) and Minitab 13.2 (Minitab Inc., State College, PA, USA). Calibration was performed with a series of $\mathrm{Cd}, \mathrm{Pb}$, and $\mathrm{Zn}$ standards. Sensitivity (m) was the slope value obtained by least-square regression analysis of calibration curves based on peak area measurements. The linear range of the calibration curve ranged from the quantification limit up to $100 \mu \mathrm{g} / 1$ was used for all trace and toxic elements. 


\section{Results}

The concentrations of $\mathrm{Zn}$ in the scalp hair samples of Irish male referent non-smokers (RNS) and referent smokers (RS) were significantly higher at 95\% confidence interval (CI) (196207) and (175-182) $\mu \mathrm{g} / \mathrm{g}$, respectively, than those values observed for rheumatoid arthritis non-smokers (RANS) and rheumatoid arthritis smokers patients (RAS) (CI=131-140 and $\mathrm{CI}=120-124 \mu \mathrm{g} / \mathrm{g}$, respectively, with $\mathrm{P}<0.001)$. In Pakistani subjects, Zn levels in the scalp hair samples of RANS and RAS $(\mathrm{CI}=130-146$ and $\mathrm{CI}=106-118 \mu \mathrm{g} / \mathrm{g}$, respectively) were found to be lower than those in RNS and RS ( $\mathrm{CI}=239-258$ and $\mathrm{CI}=216-233[\mu \mathrm{g} / \mathrm{g}$, respectively, $\mathrm{P}<0.001$ ) (Table 6). An elevated level of Cd content was observed in the scalp hair of Irish RANS and RAS. The ranges of Cd in the scalp hair samples of RNS and RS were CI 0.64-0.73 and CI 0.87-1.00 $\mu \mathrm{g} / \mathrm{g}$, respectively, whereas those in RANS and RAS were CI 1.98-2.32 $\mu \mathrm{g} / \mathrm{g}$ and CI 3.06-3.68 $\mu \mathrm{g} / \mathrm{g}$, respectively $(\mathrm{P}<0.001)$. The same trend was observed in Pakistani subjects (Table 6). The $\mathrm{Pb}$ concentration in the scalp hair samples of Irish RAS was found in the range of CI 3.15-3.56 $\mu \mathrm{g} / \mathrm{g}$, whereas in the RANS, the Pb level was in the range of CI 4.38-4.71 $\mu \mathrm{g}$ (Table 6). Similarly, a higher level of $\mathrm{Pb}$ was observed in RAS (CI 5.22-6.08 $\mu \mathrm{g} / \mathrm{g})$ than in RS $(\mathrm{P}<0.001)$. The same trend was observed in Pakistani subjects (Table 6).

\begin{tabular}{|c|c|c|c|c|c|c|c|}
\hline \multirow{10}{*}{$\begin{array}{l}\text { Table } 6 \text { Concentrations of trace } \\
\text { and toxic metals in scalp hair } \\
\text { samples of Irish and Pakistani } \\
\text { male smokers and non-smokers } \\
\text { referent and rheumatoid arthritis } \\
(\mathrm{RA}) \text { subjects }(\mu \mathrm{g} / \mathrm{g})\end{array}$} & \multirow[t]{2}{*}{ Elements } & \multicolumn{3}{|c|}{ Non-smokers } & \multicolumn{3}{|l|}{ Smokers } \\
\hline & & Referents & Rheumatoid arthritis & $P$ value & Referents & Rheumatoid arthritis & $P$ value \\
\hline & \multicolumn{7}{|c|}{ Irish subjects } \\
\hline & Cadmium & $0.68 \pm 0.07$ & $2.13 \pm 0.37$ & 0.001 & $0.94 \pm 0.12$ & $3.35 \pm 0.61$ & 0.001 \\
\hline & Lead & $3.36 \pm 0.41$ & $4.55 \pm 0.34$ & 0.009 & $3.75 \pm 0.28$ & $5.62 \pm 0.87$ & 0.003 \\
\hline & Zinc & $203 \pm 7.53$ & $135 \pm 9.42$ & 0.001 & $178 \pm 5.28$ & $122 \pm 4.63$ & 0.001 \\
\hline & \multicolumn{7}{|c|}{ Pakistani subjects } \\
\hline & Cadmium & $1.55 \pm 0.42$ & $4.59 \pm 0.51$ & 0.001 & $2.38 \pm 0.29$ & $5.86 \pm 0.63$ & 0.001 \\
\hline & Lead & $5.79 \pm 0.74$ & $9.34 \pm 0.72$ & 0.003 & $6.82 \pm 0.65$ & $11.6 \pm 1.05$ & 0.002 \\
\hline & Zinc & $250 \pm 19.3$ & $138 \pm 16.5$ & 0.001 & $225 \pm 17.1$ & $112 \pm 9.67$ & 0.001 \\
\hline
\end{tabular}

It was observed that the levels of all three elements were significantly higher in scalp hair samples of Pakistani population as compared to Irish subjects of same age group ( $\mathrm{P}=0.01$ $0.001)$.

\section{Discussion}

The present study brings out data related to the metal distribution in hair with related to arthritis disease and smoking habits in two different countries. Table 6 presents the concentration of essential trace and toxic elements $(\mathrm{Zn}, \mathrm{Cd}$, and $\mathrm{Pb})$ in scalp hair samples of Irish and Pakistani RA and referent donors. Rheumatoid arthritis is an autoimmune disease, a disorder in which the body attacks its own healthy cells and tissues. The result shows that the level of $\mathrm{Zn}$ in scalp hair samples of smokers and non-smokers RA patients was low-er than 
referents (Table 6). Zn deficiency is associated with delayed bone growth, but few studies have been done to elucidate its potential role in bone turnover regulation.

The skeleton is a major bone store of $\mathrm{Zn}$, and in humans approximately $30 \%$ of total body $\mathrm{Zn}$ is found in bone, probably bound to hydroxyapatite [20]. It has been proposed that since urinary $\mathrm{Zn}$ excretion is almost uninfluenced by variation in diet, urinary $\mathrm{Zn}$ excretion may be used as a marker of changes in bone metabolism [21]. Zinc supplementation was reported to decrease periarticular osteoporosis in RA patients [22]. Defects in skeletal development have been reported in man due to $\mathrm{Zn}$ deficiency and also due to the acrodermatitis enteropathica, an inherited congenital disorder of $\mathrm{Zn}$ absorption [23]. It has been reported that forearm bone mineral content is correlated with $\mathrm{Zn}$ intake in pre-menopausal women, suggesting a possible role of $\mathrm{Zn}$ in the maintenance of bone mass [24].

It was reported in literature that amino acid complex of $\mathrm{Zn}$ ((3-alanyl-L-histidinato zinc) has more potent effect than $\mathrm{Zn}$ sulfate on bone metabolism in experimental animals, and this $\mathrm{Zn}$ chelate has been pro-posed as a possible treatment for osteoporosis [25, 26]. The mean levels of $\mathrm{Pb}$ and $\mathrm{Cd}$ in the scalp hair samples of non-smoker referents of both countries were found to be lower than those recorded in smokers and non-smokers RA patients (Table 6). $\mathrm{Pb}$ has an exceptionally long half-life in bone (more than 20 years) compared to other elements $(\mathrm{Cu}, \mathrm{Fe}$, $\mathrm{Zn)}$ [27]; it is not the only metal which can deposit in bone from respiratory exposure. Other metals which can accumulate in bone as a result of respiratory exposure include arsenic, $\mathrm{Cd}$, cobalt, and antimony [27]. Pb can in-crease osteoporosis and it may disrupt the normal formation of Ca hydroxyapatite, thus critically weakening the bone [28].

Tandon et al. [4] in his study noted that the effects of $\mathrm{Pb}$ on humans include anemia, abdominal colic, and gum wastage, while $\mathrm{Cd}$ alters calcium (Ca) and phosphorus metabolism, thus contributing to arthritis, osteoporosis, and neuromuscular diseases. Toxic elements $(\mathrm{Cd}$, $\mathrm{Pb}$, and $\mathrm{Ni}$ ) may deplete glutathione and protein-bound sulfhydryl groups, resulting in the production of reactive oxygen species, such as superoxide anion, hydrogen peroxide, and hydroxyl radical [29]. Tobacco leaves naturally accumulate and concentrate relatively high levels of $\mathrm{Cu}$ (7.1-68.8), $\mathrm{Cd}$ (5.73-7.96), $\mathrm{Pb}(0.04-14.4)$, and $\mathrm{Ni}$ (2.21-3.45) as compared to medicinal and edible plants $\mathrm{Cu}(0.686-0.953), \mathrm{Cd}(0.072-0.12), \mathrm{Pb}(0.374-0.615)$, and $\mathrm{Ni}$ (0.31-0.523) [30, 31]; therefore, smoking of tobacco is an important source of these metals exposure for smokers [32]. The total amount of carcinogens in cigarette smoke ranges from 1 to $3 \mu \mathrm{g}$ per cigarette [13]. The country of origin and type of the product play major roles in determining the chemical composition of cigarette tobacco [32]. It was investigated that one pack of cigarettes deposits 2-4 $\mu \mathrm{g} \mathrm{Cd}, 1-2 \mu \mathrm{g} \mathrm{Pb}$, and 0.96-1.34 $\mu \mathrm{g}$ Ni into the lungs of a smoker, whereas some of the smoke passes into the air to be inhaled by smokers and nonsmokers alike [33, 34]. It was also consistent with another study that smokers generally exhibit significantly higher $\mathrm{Cd}, \mathrm{Ni}$, and $\mathrm{Pb}$ body burdens than non-smokers [32].

The results suggested that although these toxic elements $(\mathrm{Cd}, \mathrm{Ni}, \mathrm{Pb})$ pose a hazard to essential trace metal homeostasis of various organs, co-exposure can pose a major threat, while consumption of ethanol may absorb much more $\mathrm{Cd}$ and $\mathrm{Pb}$ than their unexposed counterparts [35]. In the past few years, increasing consideration has been given to 
interactions occurring in the organism between toxic metals and bioelements essential for life. These inter-actions are complex and involve biometals such as $\mathrm{Zn}, \mathrm{Cu}, \mathrm{Fe}, \mathrm{Se}, \mathrm{Ca}$, and toxic elements, including $\mathrm{Cd}$ [36]. The basis of Cd toxicity is its negative influence on enzymatic systems of cells, resulting from substitution of other essential metal ions (mainly $\mathrm{Zn}, \mathrm{Cu}$, and $\mathrm{Ca}$ ) in metalloenzymes and its very strong affinity to biological structures containing — SH groups, such as proteins, enzymes, and nucleic acids [37].

The relevance of $\mathrm{Cd}$ and $\mathrm{Pb}-\mathrm{Zn}$ interactions should be considered in the light of the general population exposure to toxic metals [38] and common deficiency of $\mathrm{Zn}$ in the world, mainly due to nutritional factors [39]. This is the first study with comprehensive data on toxic and essential elements in the scalp hair samples of male rheumatoid arthritis and referent smokers and non-smokers subjects of two countries (Pakistan and Ireland). The con-centrations of essential trace and toxic elements in scalp hair samples of the Irish referent subjects were close to those reported from other European [36-42], American [43-45], and Australian [46] countries (Table 7). The elemental con-centrations of $\mathrm{Cd}$ and $\mathrm{Pb}$ in Pakistani referents were almost higher than in European countries, which are in agreement with the studies carried out in Asian [2, 47-59] and African countries [60-64] (Table 7).

Humans are also affected by Cd through smoking and consumption of foods and beverages. Rice is the main source of $\mathrm{Cd}$ in rice-eating countries. Human $\mathrm{Pb}$ exposure is mainly through air and food. In most developed countries, the fuel content of $\mathrm{Pb}$ has been controlled but still remains an issue of immediate consideration in developing countries, including Pakistan. Other sources of $\mathrm{Pb}$ exposure include $\mathrm{Pb}$-based paints, $\mathrm{Pb}$ pipelines in water supply systems, and ceramics. The Pb-based products, including paints and food containers, are not completely banned in Pakistan [65].

\section{Conclusion}

It can be concluded that impaired trace element metabolism of the essential trace and toxic elements may have a role in the pathogenesis and progression of arthritis. The really overlooked issue here is the dramatic impact of the toxic metals on human health.

Commonly, when the body burden of these metals is in excess, the symptoms manifest in the form of muscle and joint complaints. This is because heavy metals interfere with the normal biochemical processes involving $\mathrm{Zn}$ and other nutrients in the cells of human body. When these essential minerals in the body are disrupted by heavy metals, musculoskeletal symptoms such as muscle and joint pain commonly occur. These toxic metals impair the immune system, cause abnormal cell responses, and may aggravate our sign and symptom of arthritis disorders. It is necessary to add these minerals via food supplements.

The results of this study provided guidance to clinicians and other professional investigating deficiency of essential trace metals and excessive level of toxic metals in biological samples of healthy and arthritis patients. 


\begin{tabular}{|c|c|c|c|c|c|c|c|c|c|}
\hline \multirow[t]{2}{*}{ Authors } & \multirow[t]{2}{*}{ Elements } & \multirow{2}{*}{$\begin{array}{l}\text { Age } \\
\text { (years) }\end{array}$} & \multirow[t]{2}{*}{$N$} & \multirow[t]{2}{*}{$x \pm s(\mu \mathrm{g} / \mathrm{g})$} & Authors & Elements & $\begin{array}{l}\text { Age } \\
\text { (years) }\end{array}$ & $N$ & $x \pm s(\mu \mathrm{g} / \mathrm{g})$ \\
\hline & & & & & & $7 \mathrm{z}$ & $51=$ & 18 & $270+465$ \\
\hline \multicolumn{5}{|l|}{ Europe } & \multicolumn{5}{|l|}{ India } \\
\hline \multicolumn{5}{|l|}{ Sweden } & \multirow{3}{*}{$\begin{array}{l}\text { Vishwanathan } \\
\text { et al. [53] }\end{array}$} & $\mathrm{Pb}$ & $36 \pm 1.23$ & 25 & $24.8 \pm 5.92$ \\
\hline \multirow{3}{*}{$\begin{array}{r}\text { Rodushkin and } \\
\text { Axelsson [40] }\end{array}$} & $\mathrm{Pb}$ & $1-75$ & 114 & $0.22-7.26$ & & $\mathrm{Cd}$ & $36 \pm 1.23$ & 25 & $5.12 \pm 3.41$ \\
\hline & $\mathrm{Cd}$ & $1-75$ & 114 & $0.010-0.356$ & & $\mathrm{Zn}$ & $36 \pm 1.23$ & 25 & $265.2 \pm 17.3$ \\
\hline & $\mathrm{Zn}$ & $1-75$ & 114 & $68-198$ & \multirow{5}{*}{$\begin{array}{l}\text { Sukumar and } \\
\text { Subramanian } \\
{[54]}\end{array}$} & $\mathrm{Pb}$ & $31-45$ & 17 & $8.9 \pm 1.9$ \\
\hline \multicolumn{5}{|l|}{ Poland } & & & $46-60$ & 11 & $4.5 \pm 2.8$ \\
\hline \multirow{3}{*}{$\begin{array}{l}\text { Nowak and } \\
\text { Chmielnicka [41] }\end{array}$} & $\mathrm{Pb}$ & $25-39$ & 624 & $4.8-5.7$ & & $\mathrm{Cd}$ & $31-45$ & 17 & $1.5 \pm 0.3$ \\
\hline & $\mathrm{Cd}$ & $25-39$ & 624 & $0.56 \pm 2.3$ & & & $46-60$ & 11 & $1.9 \pm 0.5$ \\
\hline & $\mathrm{Zn}$ & $25-39$ & 624 & $132.7 \pm 135.7$ & & $\mathrm{Zn}$ & $31-45$ & 17 & $87.0 \pm 1.9$ \\
\hline \multirow{4}{*}{$\begin{array}{l}\text { Trojanowski } \\
\text { et al. [42] }\end{array}$} & $\mathrm{Pb}$ & $26-50$ & 109 & $3.71 \pm 0.29$ & & & $46-60$ & 11 & $112.8 \pm 25.3$ \\
\hline & $\mathrm{Cd}$ & & 109 & $0.401 \pm 0.035$ & Mehra and & $\mathrm{Pb}$ & $1-30$ & 50 & $7.60 \pm 6.44$ \\
\hline & $\mathrm{Pb}$ & $51-75$ & 121 & $3.88 \pm 0.35$ & Juneja [55] & $\mathrm{Cd}$ & $1-30$ & 50 & $0.32 \pm 0.21$ \\
\hline & $\mathrm{Cd}$ & & 121 & $0.260 \pm 0.022$ & & $\mathrm{Zn}$ & $1-30$ & 50 & $182.4 \pm 45.2$ \\
\hline Italy & & & & & Rao et al. [56] & $\mathrm{Cd}$ & $17-60$ & 20 & $0.12-0.61$ \\
\hline Sturaro et al. [43] & $\mathrm{Zn}$ & $21-60$ & 50 & $171-314$ & & $\mathrm{Zn}$ & $17-60$ & 20 & $45.44-123.5$ \\
\hline & $\mathrm{Pb}$ & $21-60$ & 50 & $6.5-8.7$ & & $\mathrm{~Pb}$ & $17-60$ & 20 & $0.75-4.1$ \\
\hline France & & & & & Turkey & & & & \\
\hline Goulle et al. [44] & $\mathrm{Zn}$ & $40-60$ & 45 & $129-209$ & Sasmaz et al. [57] & $\mathrm{Pb}$ & - & 26 & $3.06 \pm 1.42$ \\
\hline & $\mathrm{Pb}$ & $40-60$ & 45 & $0.13-4.57$ & & $\mathrm{Cd}$ & - & 26 & $0.67 \pm 0.33$ \\
\hline Netherlands & & & & & Ulvi et al. [58] & $\mathrm{Zn}$ & $47.76 \pm 13.11$ & 29 & 176.96 \\
\hline $\begin{array}{l}\text { Iyengar and } \\
\text { Wolttlez }\end{array}$ & $\mathrm{Zn}$ & $21-60$ & 50 & $176 \pm 38$ & Hong Kong & & & & \\
\hline South America & & & & & Man and Zheng [59] & $\mathrm{Pb}$ & $20-50$ & 30 & $12.04 \pm 7.0$ \\
\hline Nagra et al. [46] & $\mathrm{Cd}$ & $22-59$ & 50 & $31.6 \pm 38$ & & $\mathrm{Zn}$ & $20-50$ & 30 & $184.85 \pm 60.89$ \\
\hline North America & & & & & Man et al. [60] & $\mathrm{Zn}$ & $30-69$ & 95 & $355-503$ \\
\hline Saiki et al. [47] & $\mathrm{Zn}$ & $50-70$ & 50 & $45-162$ & Africa & & & & \\
\hline & $\mathrm{Zn}$ & $71-87$ & 50 & $30-202$ & $\begin{array}{l}\text { Nigeria } \\
\text { Nnorom et al. [61] }\end{array}$ & $\mathrm{Pb}$ & $1-30$ & 46 & 63.6 \\
\hline $\begin{array}{l}\text { Australia } \\
\text { McKenzie }\end{array}$ & $7 \mathrm{n}$ & $16-56$ & 118 & $189+24$ & [N & $\mathrm{Cd}$ & $1-30$ & 46 & $\begin{array}{l}05.0 \\
1.0\end{array}$ \\
\hline Asia & & $10-50$ & & $189 \pm 24$ & & $\mathrm{Zn}$ & $1-30$ & 46 & 128.6 \\
\hline Pakistan & & & & & Syria & & & & \\
\hline & $\mathrm{Pb}$ & $15-94$ & 86 & $14.62 \pm 8.01$ & Khuder et al. [62] & $\mathrm{Pb}$ & $21-59$ & 281 & $10.7 \pm 8.9$ \\
\hline & & & & $(0.577-31.8)$ & & $\mathrm{Zn}$ & $21-59$ & 281 & $260 \pm 113$ \\
\hline & $\mathrm{Cd}$ & $15-94$ & 86 & $2.13 \pm 1.74$ & Sudan & & & & \\
\hline & & & & $(0.196-9.17)$ & Eltayeb and & $\mathrm{Zn}$ & $30-50$ & 35 & $89-170$ \\
\hline & $\mathrm{Zn}$ & $15-94$ & 86 & $\begin{array}{c}154.2 \pm 117.1 \\
\quad(12.4-729.2)\end{array}$ & $\begin{array}{l}\text { Van-Grieken [63] } \\
\text { Egypt }\end{array}$ & $\mathrm{Pb}$ & $30-50$ & 35 & $3-17$ \\
\hline Pasha et al. [50] & $\mathrm{Pb}$ & $37-65$ & 37 & $15.50 \pm 8.11$ & Mortada & $\mathrm{Pb}$ & $28-40$ & 93 & $1.8-9.7$ \\
\hline & $\mathrm{Cd}$ & $37-65$ & 37 & $1.675 \pm 1.13$ & et al. [64] & $\mathrm{Cd}$ & & 93 & \\
\hline & $\mathrm{Zn}$ & $37-65$ & 37 & $140.7 \pm 79.5$ & & & & & \\
\hline Shah et al. [51] & & & & & & & & & \\
\hline (Pak) & $\mathrm{Pb}$ & $3-54$ & 62 & $15.97 \pm 5.56$ & & & & & \\
\hline (Lib) & & $3-54$ & 62 & $24.95 \pm 8.69$ & & & & & \\
\hline (Pak) & $\mathrm{Cd}$ & $3-54$ & 62 & $0.38 \pm 0.186$ & & & & & \\
\hline (Lib) & & $3-54$ & 62 & $0.53 \pm 0.26$ & & & & & \\
\hline (Pak) & $\mathrm{Zn}$ & $3-54$ & 62 & $226 \pm 53.7$ & & & & & \\
\hline (Lib) & & $3-54$ & 62 & $190 \pm 34.0$ & & & & & \\
\hline Khalique et al. [52] & $\mathrm{Cd}$ & $41-50$ & 18 & $0.300 \pm 0.140$ & & & & & \\
\hline
\end{tabular}

This study also provides some support for the hypothesis that dietary intake or inhalation of toxic elements $(\mathrm{Cd}$ and $\mathrm{Pb})$, most probably through smoking cigarette, may increase the risk of rheumatoid arthritis and related disorders, which indicates that the causal link may be stronger among cigarette smokers. We propose that essential and toxic elemental 
measurements may be performed on patients reaching in the emergency department to test whether its concentration may serve not only as markers of rheumatoid arthritis and its remedies but also as predictors of adverse outcomes.

Acknowledgment Dr. Hassan Imran Afridi is grateful to Higher Education Commission (HEC) of Pakistan for providing the scholar-ships for the post-doctoral research work. Dr. H.I. Afridi is also thankful to National Center of Excellence in Analytical Chemistry, University of Sindh, Jamshoro, Pakistan for the grant of sabbatical leave.

\section{References}

1. Gennari C (2001) Calcium and vitamin D nutrition and bone disease of the elderly. Public Health Nutr 4:547-559

2. Sandstead HH, Penland JG, Alcock NW, Dayal HH, Chen XC, Li JS, Zhao F, Yang JJ (1998) Effects of repletion with zinc and other micronutrients on neuropsychologic performance and growth of Chinese children. Am J Clin Nutr 68:470S-5S

3. Grynpas MD (1990) Fluoride effects on bone crystals. J Bone Mineral Res 5: S169-S175

4. Tandon SK, Chatterjee M, Bhargava A, Shukla V, Bihari V (2001) Lead poisoning in Indian silver refiners. Sci Total Environ 281:177-182

5. Tudor R, Zalewski PD, Ratnaike RN (2001) Zinc in health and chronic disease. Scand J Rheumatol 30:208-212

6. Adeniyi FA, Heaton FW (1980) The effect of zinc deficiency on alkaline phosphatase (EC 3.1.3.1) and its isoenzymes. Br J Nutr 43:561-569

7. Starcher BC, Hill CH, Madaras JG (1980) Effect of zinc deficiency on collagenase and collagen turnover. J Nutr 110:2095-102

8. Calhoun NR, Smith JC Jr, Becker KL (1974) The role of zinc in bone metabolism. Clin Orthop Relat Res 103:212-34

9. Kishi S, Yamaguchi M (1994) Inhibitory effect of zinc compounds on osteoclast-like cell formation in mouse marrow cultures. Bio-chem Pharmacol 48:1225-1230

10. Kozlowski LT, Connor RJ (2002) Cigarette filter ventilation is a defective design because of misleading taste, bigger puffs, and blocked vents. Tob Control

11:140-150 11. Wagner GJ (1993) Accumulation of cadmium in crop plants and its consequences to human health. Adv Agron 51:173-212

12. Chiba M, Masironi R (1992) Toxic and trace-elements in tobacco and tobacco-smoke. Bull WHO 70:269-275 
13. Csalari J, Szantai K (2002) Transfer rate of cadmium, lead, zinc and iron from the tobacco-cut of the most popular Hungarian cigarette brands to the combustion products. Acta Aliment 31:279-288

14. Klaus KA, Witte MB, Andrew L, Clark MA, John GF (2001) Chronic heart failure and micronutrients. J Am Coll Cardiol 37:1765-1774

15. Witte KKA, Nikitin NP, Parker AC et al (2005) The effect of micronutrient supplementation on quality-of-life and left ventricu-lar function in elderly patients with chronic heart failure. Eur Heart J 26:2238-2244

16. Kazi TG, Afridi HI, Kazi N et al (2008) Distribution of zinc, copper and iron in biological samples of Pakistani myocardial infarction (1st, 2nd and 3rd heart attack) patients and controls. Clin Chim Acta 389:114-119

17. Afridi HI, Kazi TG, Kazi N et al (2008) Evaluation of status of toxic metals in biological samples of diabetes mellitus patients. Diabetes Res Clin Pract 80:280-288

18. Huang CC, Yang MH, Shih TS (1997) Automated on-line sample pretreatment system for the determination of trace metals in bio-logical samples by inductively coupled plasma mass spectrometry. Anal Chem 69(19):3930-3939

19. Afridi HI, Kazi TG, Kazi GH et al (2006) Analysis of heavy metals in scalp hair samples of hypertensive patients by conventional and microwave digestion methods. Spect letter 39:203-214

20. Sauer GR, Wuthier RE (1990) Distribution of zinc in the avian growth plate. J Bone Miner Res 5:S162

21. Relea P, Revilla M, Ripoll E et al (1995) Zinc, biochemical markers of nutrition, and type I osteoporosis. Age Ageing 24:303-307

22. Honkanen VEA, Lamberg-Allardt CH, Vesterinen MK et al (1991) Plasma zinc and copper concentrations in rheumatoid arthritis: influence of dietary factors and disease activity. Am J Clin Nutr 54:1082-1086

23. Michael HK, Carolyn H, Margaret J, David BJ (1972) Low levels of zinc in hair, anorexia, poor growth, and hypogeusia in children. Pediatr Res 6:868-874

24. Angus RM, Sambrook PN, Pocock NA, Eisman JA (1988) Dietary intake and bone mineral density. Bone Miner 4:265-77

25. Yamaguchi M (1990) P-Alanyl-L-histidinato zinc and bone resorp-tion. Gen Pharmacol Vasc S 26:1179-1183

26. Yamaguchi M (1998) Role of zinc in bone formation and bone resorption. J Trace Elem Exp Med 11:119-135 
27. Aufderheide AC (1989) Chemical analysis of skeletal remains. In: Iscan MY, Kennedy KAR (eds) Reconstruction of life from the skeleton. Liss, New York, pp 237-260

28. Skinner HCW (2000) In praise of phosphates, or why vertebrates chose apatite to mineralise their skeletal elements. Geol Int 42:232-240

29. Goyer RA (1996) Toxic effects of metals. In: Klaassen CD (ed) Casarett and Doull's toxicology: the basic science of poisons, vol. 5. McGraw-Hill, New York, pp 691-736

30. Sahito SR, Kazi TG, Kazi GH, Memon MA, Shaikh Q, Jakhrani MA, Shar GQ (2003) Comparison of sample preparation methods for the determination of essential and toxic elements in important indigenous medicinal plant Aloe barbadensis. J Chem Soc Pak 25 (2):201-205

31. Arain MB, Kazi TG, Jamali MK, Jalbani N, Afridi HI, Kandhro GA et al (2008) Hazardous impact of toxic metals on tobacco leaves grown in contaminated soil by ultrasonic assisted pseudo-digestion: multivariate study. J Haz Mat 155:216-224

32. Kazi TG, Jalbani N, Arain MB, Jamali MK, Afridi HI et al (2009) Toxic metals distribution in different components of Pakistani and imported cigarettes by electrothermal atomic absorption spectrom-eter. J Haz Mat 163:302-307

33. Hecht SS (2003) Tobacco carcinogens, their biomarkers and tobacco-induced cancer. Nat Rev Cancer 3:733-744

34. Kazi TG, Jalbani N, Arain MB, Jamali MK, Afridi HI, Shah AQ (2009) Determination of toxic elements in different brands of cigarette by atomic absorption spectrometry using ultrasonic assis-ted acid digestion. Environ Monit Assess 154:155-167

35. Sharma G, Sandhir R, Nath R, Gill K (1991) Effect of ethanol on cadmium uptake and metabolism of zinc and copper in rats ex-posed to cadmium. J Nutr 121:87-91

36. Brzoska MM, Moniuszko-Jakoniuk J, Jurczuk M, Chraniuk M (1997) The influence of cadmium on bone tissue in rats. Pol J Environ Stud 6:29-32

37. Stohs SJ, Bagchi D (1995) Oxidative mechanisms in the toxicity of metal ions. Free Radic Biol Med 18:321-336

38. Waalkes MP, Coogan TP, Barter RA (1992) Toxicological princi-ples of metal carcinogenesis with special emphasis on cadmium. Crit Rev Toxicol 22:175-201

39. Lonnerdal B (1993) Dietary factors influencing zinc absorption. J Nutr 130:1378-1383

40. Rodushkin I, Axelsson MD (2000) Application of double focusing sector field ICP-MS for multielemental characterization of human hair and nails. Part II. A study of the inhabitants of northern Sweden. Sci Total Environ 262:21-36 
41. Nowak B, Chmielnicka J (2000) Relationship of lead and cadmi-um to essential elements in hair, teeth, and nails of environmentally exposed people. Ecotoxic Environ Safety 46:265274

42. Trojanowski P, Trojanowski J, Antonowicz J, Bokiniec M (2010) Lead and cadmium content in human hair in central Pomerania (northern Poland). J Elementol 15(2):363-384

43. Sturaro A, Parvoli G, Doretti L (1993) Simultaneous determination of trace metals in human hair by dynamic ion-exchange chroma-tography. Anal Chim Acta 274:163-170

44. Goulle JP, Mahieu L, Castermant J, Neveu N, Bonneau L, Laine G, Bouige D, Lacroix C (2005) Metal and metalloid multi-elementary ICP-MS validation in whole blood, plasma, urine and hair refer-ence values. Forensic Sci Int 153:39-44

45. Iyengar V, Wolttlez $\mathrm{J}$ (1988) Trace elements in human clinical specimens: evaluation of literature data to identify reference val-ues. Clin Chem 34(3):474-481

46. Naga MS, Pallah BS, Sahota GPS, Singh H, Sahota HS (1992) A study of trace elements in scalp hair and fingernails of industrial workers of Ontario, Canada. J Radioanal Nucl Chem 162(2):283-288

47. Saiki M, Alves ER, Jaluu 0, Sumita NM, Filho WJ (2008) Deter-mination of trace elements in scalp hair of an elderly population by neutron activation analysis. J Radioanal Nucl Chem 276(1):53-57

48. McKenzie JM (1979) Content of zinc in serum, urine hair and toenails of New Zealand adults. Am J Clinical Nutr 32:570-579

49. Pasha Q, Malik SA, Iqbal J, Shaheen N, Shah MH (2008) Com-parative distribution of the scalp hair trace metal contents in the benign tumour patients and normal donors. Environ Monit Assess 147:377-388

50. Pasha Q, Malik SA, Shaheen N, Shah MH (2010) Investigation of trace metals in the blood plasma and scalp hair of gastrointestinal

cancer patients in comparison with controls. Clin Chim Acta 411:531-539

51. Shah MH, Shaheen N, Khalique A, Alrabti AAA, Jaffar M (2006) Comparative metal distribution in hair of Pakistani and Libyan population and source identification by multivariate analysis. En-viron Monit Assess 114:505-519

52. Khalique A, Ahmad S, Anjum T, Jaffar M, Shah MH, Shaheen N, Tariq SR, Manzoor S (2005) A comparative study based on gender and age dependence of selected metals in scalp hair. Environ Monit Assess 104:45-57

53. Vishwanathan H, Hema A, Edwin D, Usha Rani MV (2002) Trace metal concentration in scalp hair of occupationally exposed auto drivers. Environ Monit Assess 77:149-154 
54. Sukumar A, Subramanian (2003) Elements in the hair of non-mining workers of a lignite open mine in Neyveli. Indust Health 41(2):63-68

55. Mehra R, Juneja M (2005) Elements in scalp hair and nails indi-cating metal body burden in polluted environment. J Sci Ind Res 64(2):119-124

56. Rao KS, Balaji T, Rao TP, Babu Y, Naidu GRK (2002) Determi-nation of iron, cobalt, nickel, manganese, zinc, copper, cadmium and lead in human hair by inductively coupled plasma atomic emission spectrometry. Spectrochim Acta Part B

57:1333-1338 57. Sasmaz S, Uz E, Pinar T, Vural H, Eiri M, Ilihan A, Akyol 0 (2003) Hair lead and cadmium concentrations in patients with epilepsy and migraine. Neurosci Res Commune 32:107-114

58. Ulvi H, Yigiter R, Yoldas TS, Dolu Y, Var A, Mungen B (2002) Magnesium, zinc and copper contents in hair and their serum concentrations in patients with epilepsy. Eastern $\mathbf{J}$ Medicine 7:31-35

59. Man CK, Zheng YH, Mak PK (1996) Trace element profiles in the hair of nasopharyngeal carcinoma (NPC) patients. J Radioanal Nucl Chem Letters 212:151-160

60. Man CK, Zheng YH (2002) Analysis of trace elements in scalp hair of mentally retarded children. J Radioanal Nucl Chem 253:375-377

61. Nnorom IC, Igwe JC, Ejimone JC (2005) Multielement analyses of human scalp hair samples from three distant towns in southeastern Nigeria. African J Biotech 4:1124-1127

62. Khuder A, Bakir MA, Hasan R, Mohammad A (2008) Determina-tion of nickel, copper, zinc and lead in human scalp hair in Syrian occupationally exposed workers by total reflection X-ray fluores-cence. Environ Monit Assess 143:67-74

63. Eltayeb MAH, Van-Grieken RE (1989) Preconcentration and XRF determination of heavy metals in hair from Sudanese populations. J Radioanal Nucl Chem 131:331-342

64. Mortada WI, Sobh MA, El-Defrawy MM, Farahat SE (2002) Reference intervals of cadmium, lead, and mercury in blood, urine, hair, and nails among residents in Mansoura City, Nile Delta, Egypt. Environ Res Section A 90:104-110

65. Hozharbi S (2002) Lead-based paint is a hazard to young children: implications for Pakistani children. J Pak Med Assoc 5:224-226 